\title{
Commentary on The Psychology of Creativity: A Critical Reading by Vlad P. Glăveanu
}

\author{
David H. Cropley \\ University of South Australia \\ E-mail address: David.Cropley@unisa.edu.au
}

\section{ARTICLE INFO}

\section{Keywords:}

4P paradigm

Inconvenient samples

\section{Article history:}

Received 3 November 2014

Received in revised form 18 December 2014

Accepted 19 December 2014

ISSN: 2354-0036

DOI: 10.15290/ctra.2014.01.02.08

\section{A B S TR A C T}

\begin{abstract}
The psychology of creativity is in crisis! This is the assertion of Glăveanu's thought-provoking and wide-ranging review. The present commentary responds to each of Glăveanu's six conclusions - supporting some and challenging others finding much to drive an exciting future of research in creativity. Bold, new and surprising questions do, indeed, need to be asked in this field. Reflection on definitions of creativity is, as Glăveanu asserts, important, but should not divert researchers from moving forward, confident that a consensus does exist. Reductionist approaches in creativity research should not overwhelm attempts to integrate the contributions of the 4Ps as a system. Creativity research should seek out and study inconvenient samples - professional practitioners, for example. Qualitative, theory-building approaches to creativity research need to be encouraged as a counter-balance to quantitative theory-testing. Lastly, and perhaps most importantly for the future health of creativity, researchers need to demonstrate to the wider scientific community the value that creativity brings to other disciplines. If the community of creativity researchers, psychological or otherwise, contributes to Glăveanu's suggestions for future research, then the fragmentation and dispersion he identifies are, in fact, the seeds of future health.
\end{abstract}

\section{COMMENTARY}

Glăveanu's (2014) article raises many interesting and important points about the nature and status of creativity research, with perhaps the most important being the need for "dialogue and collaboration" (Glăveanu, 2014, p. 28). While I agree that there is much that could be done differently, and possibly better, I would stop short of claiming that "the psychology of creativity is close to a crisis" (Glăveanu, 2014, p. 10). Nevertheless, like the recent special section on Replications in Psychology prompted by Makel's article in the journal Psychology of Aesthetics, Creativity, and the Arts (Makel, 2014), wide-ranging discussion should be encouraged and supported. 
My own position in the debate is influenced by two facts. First, my creativity heritage, so to speak, is largely psychological in nature. Although not a psychologist, I came to the field through the tutelage of researchers embedded in the psychology of creativity, so that if Schools of Thought can be said to exist in creativity research, then I tend to see myself as a product of the Psychological School of Creativity. Second, my professional heritage is engineering. Where this influences my views on creativity is probably most strongly seen in my particular interest in practical applications of creativity. As an engineer, what concerns me most - and the question I most often have to address when talking to colleagues and potential engineering clients - is the "so what" of creativity. What value does it add to a discipline like engineering? Why should an engineering firm, or the engineering department of a University, for that matter, care about creativity?

Glăveanu's article therefore strikes several strong chords for me, although with some differences in detail. In a very general sense, for example, I am not particularly troubled by the "increased fragmentation and dispersion" that he cites (Glăveanu, 2014, p. 10). Indeed, I do not see how growth can be anything other than divergent, and the idea of convergent growth (Glăveanu, 2014, p. 10) seems inherently limiting. Convergent growth, to me, implies constraint and limitation, or worse, gatekeeping. The question of what creativity studies are developing towards does not, in my opinion need to be answered in a way that limits possibilities - it is sufficient, to say that it IS developing. To put this differently, if it must develop towards something, it is sufficient that the goal is an increase in the body of knowledge, however broad, diffuse or fragmented that might be. I am in favour of an approach that is essentially market-driven - certain themes, methods, theories and so on will prevail, because they have explanatory power and help to explain the value of creativity, while others will fade out naturally because they lack explanatory power. The important point is that the value and ultimate success of certain lines of creativity research is an emergent property of the system. Indeed, if we knew which lines of attack to pursue, in advance - if we knew what is what we were supposed to be doing - then, in the words of Albert Einstein, “it wouldn't be called research, would it?!"

Glăveanu's article covers a lot of ground and while I would like to address many of his points - to support some, or to extend or contest others - space does not permit a lengthy commentary. Instead, I will address his six conclusions for future research, and hope that, for the remainder, the opportunity arises in journals like this one to engage in these debates that he correctly points out are vital to the health of creativity research.

1. Ask bold, new, and surprising questions. I agree with this point, and would highlight a concern of my own. The consumer - of the research - should be ultimate judge of the 
value and worth of research. There is a danger that journal reviewers, for example, act as gatekeepers rather than quality controllers. My view is that the function of reviewers and editors is to weed out papers that are methodologically unsound, or poorly written, or that contain factual errors, but not to block papers that contain new or untested ideas. If in doubt, let the reader be the judge of what constitutes a bold, new, or surprising question.

2. Reflect on definitions, do not simply take them for granted. To some extent - yes. However, in engineering, for example, I see many papers that show a desire to explore creativity, but never get past the initial hurdle of "what is creativity?" The typical response seems to be to ignore the extant body of knowledge, i.e. the psychology of creativity, and instead, start from first principles. The problem with this approach is that, ironically, these engineers are spending a great deal of time and effort reinventing the creativity wheel, and the initial burst of enthusiasm fizzles out after the effort of trying to define creativity. In other words, little progress is made, and little is added to the body of knowledge. In application areas, like engineering, more progress would be made by taking some of the existing work on creativity for granted - not least the definition - and working forward from that point.

3. Challenge traditional units of analysis. I agree with Glăveanu's point that much of creativity research is very reductionist, or Cartesian, in nature. Outside of creativity research, my own day-to-day teaching is in the field of systems engineering, and we teach that a complex system cannot be analysed, or understood, by cutting it into its constituent parts. Doctors do not learn about life by cutting living systems into their component parts, because life is an emergent property of the system. It is manifest only at the level of the system, when the components of the system are interacting and exchanging energy, information and/or mass. Glăveanu's point is that creativity is a system, and there are limitations in trying to study it by reducing it to its component parts - the 4Ps - each in isolation from the other.

4. Look for unique, interesting samples and develop new methods. I support Glăveanu's call for research in creativity to move "beyond psychology students and acknowledged creators as participants" (Glăveanu, 2014, p. 28). Of course, researchers are constrained by practicalities of data collection, but we need to have a debate about this and ask, for example, if it is better to have a convenience sample of 500 psychology students, or a sample of only 50 school children, or engineering students, or Nobel Laureates. Simonton (2014) discusses a broadly similar issue in his response to Makel's (2014) article.

5. Build theory, don't just cite it. I agree with Glăveanu's point here - "literature reviews and discussion sections are not simply an occasion to cite the works you are expected 
to cite..." (Glăveanu, 2014, p. 28) - but I see two possible causes. We need to guard against the positive feedback loop that can be created by the review process. If we place too much emphasis on reinforcing what we feel are standard works, there is a danger that papers converge on a small number of expected references at the exclusion of other material. The solution is not to stop asking researchers to make sure they have cited important works, but to invite them to add other works at the periphery, and to accept these even if they are unfamiliar. A second issue here, touched on by Glăveanu, is the relative lack of qualitative research in creativity - or perhaps, the lack of availability of avenues to publish more qualitative work. One way to categorise the difference between qualitative and quantitative research is that the former is theory building, while the latter is theory testing. If we want creativity researchers to build theory, then there needs to be an outlet for qualitative studies that do this.

6. Think practically about your conclusions. The key point raised here by Glăveanu relates to the "so what?" In my own discipline, I think there is a desperate need and desire to understand the contribution that creativity (and innovation) make, in real, practical terms to the process of solving technological problems. I have attempted to address this myself (Cropley, 2015), but I feel that mine is still largely a lone voice. The same might be said of other applications of creativity. There is a strong desire in engineering, education and other disciplines to understand and make use of creativity for practical purposes, and we need to sell the value of creativity to these disciplines in an effective and clear manner.

I will close as I started. I do not think that the psychology of creativity is as close to crisis as Glăveanu suggests. However, this does not mean that debate, discussion and action are not warranted. The health of any area of research should be measured by the level of internal debate, and its openness to new and different points of view, theories and methods. Could the psychology of creativity do better in this respect? No doubt. Is the psychology of creativity - or creativity research more generally - in crisis? It may be, to a degree, fragmented, dispersed and chaotic, but I see these as signs of discipline that is still in its adolescence - and this will naturally change and coalesce as it continues to mature.

\section{REFERENCES}

Cropley, D.H. (2015). Creativity in Engineering: Novel solutions to complex problems. San Diego: Academic Press.

Glăveanu, V.P. (2014). The Psychology of Creativity: A Critical Reading. Creativity: Theories - Research - Applications, 1, 10-32, DOI: 10.15290/ctra.2014.01.01.02. 
Makel, M.C. (2014). The empirical march: Making science better at self-correction. Psychology of Aesthetics, Creativity, and the Arts, 8, 1, 2-7.

Simonton, D.K. (2014). Significant Samples - Not Significant Tests! The Often Overlooked Solution to the Replication Problem. Psychology of Aesthetics, Creativity, and the Arts, 8, 1, 11-12.

Corresponding author at: David H. Cropley, Defence and Systems Institute, University of South Australia, Building W, Mawson Lakes Campus, Mawson Lakes, SA 5158, Australia. Email: David.Cropley@unisa.edu.au 